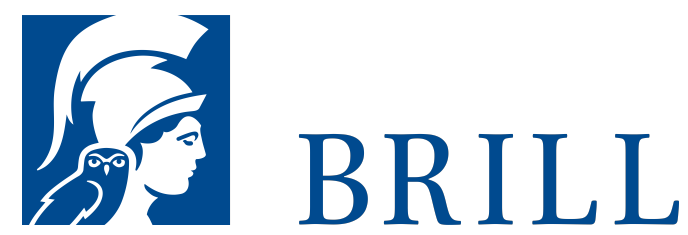

\title{
Umberto Eco
}

Philosophie - Ästhetik - Semiotik

Author: Grit Fröhlich

Zum ersten Mal wird Ecos semiotisches Denken ausführlich vorgestellt und vor dem Hintergrund der italienischen Philosophie und Politik der Nachkriegszeit rekonstruiert. Das Buch spürt die intellektuellen Wurzeln dieses Denkers auf und macht so die verschiedenen Stationen seiner Theorie bis zur kognitiven Semiotik der 199oer Jahre transparent. Es zeigt, wie Eco von der Ästhetik seines Lehrers Luigi Pareyson beeinflusst wurde. Außerdem wird deutlich, wie Eco sein pluralistisches, laizistisches Kulturverständnis in Abgrenzung zur katholischen Philosophie entwickelte, der er Anfang der 1950er Jahre nahe stand. Neue Einblicke gewähren Zitate aus bislang unbekannten Jugendschriften und ein Interview, in dem Eco über seine philosophische Herkunft spricht.

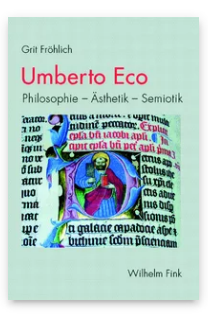

Pages: 330

Seiten

Language:

German

Subjects:

General,

Philosophy

Publisher: Brill |

Fink

E-Book (PDF)

Released online:

O2 Dec 2019

ISBN: 978-3-

8467-4880-o

List price

USD $\$ 63.00$

Paperback

Publication date:

16 Sep 2009

ISBN: $978-3^{-}$

7705-488o-4

List price

USD $\$ 63.00$ 
For more information see brill.com

Order information: Order online at brill.com +44330 333 0049 | customerservices@brill.com Submission information: brill.com/authors

Titles published by Brill | Fink, Brill | mentis or Brill | Schöningh: +49(o)715413279216| brill@brocom.de 